\title{
Erratum: Polymerase chain reaction ribotyping of Clostridium difficile isolates in Qatar: a hospital-based study
}

\author{
Asma A Al-Thani ${ }^{1 *}$, Wedad S Hamdi ${ }^{1}$, Naser A Al-Ansari ${ }^{2}$, Sanjay H Doiphode ${ }^{2}$ and Godwin Justus Wilson ${ }^{2}$
}

Following publication of this article [1] we noted that we had made an error in the authorship list. The correct details can be found as above.

The authors contributions section should be updated as follows:

A.Al-T. designed this study. Wedad Saleem performed data analysis and drafted the manuscript. N. Al-A. provided assistance with data collection and manuscript revision. S.D. collected samples and clinical data, participated in the design of the study and performed the statistical analysis. G.W. was involved in the concept and design of the study and he analysed the data. All authors read and approved the final manuscript.

\section{Author details}

'Health Sciences Department, College of Arts and Sciences, Biomedical Research Center, Qatar University, Doha, Qatar. ${ }^{2}$ Department of Laboratory medicine and Pathology, Al-Khor Hospital, Hamad Medical Corporation, Doha, Qatar.

Received: 23 January 2015 Accepted: 23 January 2015

Published online: 03 April 2015

\section{Reference}

1. Al-Thani AA, Hamdi WS, Al-Ansari NA, Doiphode SH. Polymerase chain reaction ribotyping of Clostridium difficile isolates in Qatar: a hospital-based study. BMC Infectious Diseases. 2014;14:502.

\footnotetext{
*Correspondence: aaja@qu.edu.qa

${ }^{1}$ Health Sciences Department, College of Arts and Sciences, Biomedical Research Center, Qatar University, Doha, Qatar

Full list of author information is available at the end of the article
}

Submit your next manuscript to BioMed Central and take full advantage of:

- Convenient online submission

- Thorough peer review

- No space constraints or color figure charges

- Immediate publication on acceptance

- Inclusion in PubMed, CAS, Scopus and Google Scholar

- Research which is freely available for redistribution 